Brazilian Journal

of Chemical

ISSN 0104-6632

Engineering

\title{
INFLUENCE OF TOLUENE AND SALINITY ON BIOSURFACTANT PRODUCTION BY Bacillus sp.: SCALE UP FROM FLASKS TO A BENCH-SCALE BIOREACTOR
}

\author{
E. C. Souza ${ }^{1}$, T. C. Vessoni-Penna ${ }^{1}$, S. Al Arni², J. M. Domínguez ${ }^{3}$, \\ A. Converti ${ }^{4}$ and R. P. de S. Oliveira ${ }^{1 *}$ \\ ${ }^{1}$ Biochemical and Pharmaceutical Technology Department, Faculty of Pharmaceutical Sciences, São Paulo University, \\ Av. Prof LineuPrestes, 580, B1 16, 05508-900, São Paulo, Brazil. \\ Phone: +551130910123 \\ E-mail: rpsolive@usp.br \\ ${ }^{2}$ Department of Chemical Engineering, Kind Saudi University, \\ P.O. Box 800, Riyadh 11421, Saudi Arabia. \\ ${ }^{3}$ Department of Chemical Engineering, Faculty of Sciences, Vigo University, \\ Campus of Ourense, As Lagoas s/n, 32004 Ourense, Spain. \\ ${ }^{4}$ Department of Civil, Chemical and Environmental Engineering, Pole of Chemical Engineering, Genoa University, \\ via Opera Pia 15, 16145 Genoa, Italy.
}

(Submitted: December 4, 2015; Revised: January 26, 2016; Accepted: February 8, 2016)

\begin{abstract}
To select the best biosurfactant producer, Pseudomonas putida, Bacillus megatherium, Bacillus licheniformis and Bacillus subtilis were cultured in flasks on media with different salinity [low salinity (LS), Bushnell-Haas (BH) and artificial sea water (SW) media] supplemented or not with toluene as a model pollutant. Toluene inhibited the growth of all microorganisms and stimulated the biosurfactant production. B. subtilis exhibited the best performance, being able to lower the surface tension (ST) in the LS medium to $65.5 \mathrm{mN} / \mathrm{min}$ in the absence of toluene, and to $46.5 \mathrm{mN} / \mathrm{min}$ in the $\mathrm{BH}$ medium in the presence of toluene, corresponding to ST reductions of 13.0 and $27.5 \mathrm{mN} / \mathrm{m}$, respectively. Scaling up the process to a bench-scale fermentor, the best results were obtained in the LS medium, where $B$. subtilis was able to reduce the toluene concentration from 26.0 to $4.3 \mathrm{~g} / \mathrm{L}$ within $12 \mathrm{~h}$ and ST by $17.2 \mathrm{mN} / \mathrm{m}$ within $18 \mathrm{~h}$. The results of this study point out that $B$. subtilis is an interesting biosurfactant producer, which could be used in the bioremediation of toluene-contaminated water. Keywords: Bioreactor; Toluene; Biosurfactant; Saline media; Bacillus subtilis; Bioremediation.
\end{abstract}

\section{INTRODUCTION}

Concerns related to the potential contamination of soil and water by oil and its derivatives have been gradually increasing. The main sources of contamination are: a) unintended spill during the transportation of fuels by ships and trucks; b) leaking from underground storage tanks such as those used in gas stations, which are subject to corrosion; c) oil extraction and processing operations; and d) inadequate disposal of oily wastes from industries that use oil derivatives to produce plastics, solvents, pharmaceuticals, cosmetics, etc. (Du et al., 2014; Kavitha et al., 2014).

Residues produced by such activities are composed of oils, fats, organic compounds and metals. Among the organic compounds, there are alkanes, cycloalkanes, benzene, toluene, xylenes, phenol and polycyclic aromatic hydrocarbons (Di Martino et al., 2012). Many

*To whom correspondence should be addressed 
of these compounds are considered to be extremely polluting because, besides being toxic, some of them have carcinogenic and mutagenic potential for human beings (Janbandhu and Fulekar, 2011).

The sea environment has been suffering constant oil spills, and the release of thousands of tons of petroleum contaminating the ocean has been constantly reported (Goldman et al., 2015). In Brazil, for example, one of the most impactful spills took place in November 2011, when 594.3 thousand liters of petroleum were released from the Sedco 706 platform, operated by Chevron in Campos Basin (Rio de Janeiro), creating a polluted area of about $163 \mathrm{~km}^{2}$ (Souza, 2013).

Gasoline and diesel contain hydrocarbons from the BTEX group (benzene, toluene, ethylbenzene and xylenes), which are the first ones to reach groundwater (Mariano et al., 2007). Consequently, such highly-toxic compounds (except ethylbenzene) are the major causes of death related to drinking water contamination (Di Martino et al., 2012). Fellenberg (1980) reported that petroleum and its derivatives, when in contact with water, spread creating a thin film on the surface that prevents not only gas exchange between air and water, but also light from reaching phytoplankton, thus affecting the food chain. Accordingly, Asimiea and Sam-Wobo (2011) observed a strong impact of such compounds on phytoplankton communities, which suffered structural changes. The potential threat of hydrocarbons to human health is linked to both their physical and chemical properties, which allow them to be absorbed by the skin and quickly spread throughout the organism(Costa et al., 2012).

Toluene has moderate systemic toxicity to humans. When ingested, it is completely absorbed by the gastrointestinal tract, quickly spreads through the body, especially the fatty tissues, and is metabolized and excreted through the urine. When inhaled, toluene affects the central nervous system (Fellenberg, 1980). In addition, embryotoxic and fetotoxic effects have been observed, though there is no clear evidence of teratogenic or carcinogenic activity in laboratory animals or humans (WHO, 2006; Zhang et al., 2013).

In light of the problems caused by hydrocarbons to both the environment and human beings, the search for methods able to remove such compounds or reduce their occurrence in the environment has greatly increased in the last years. The methods used to achieve this goal are based on chemical, physical or biological means. Due to the high cost of physical treatments, and to the fact that chemical methods release substances that are harmful to the local biota, research efforts have been mainly focused on developing sustainable technologies using natural biodegradable compounds (Lin et al., 2012).

Bioremediation processes, based on the use of living organisms to clean-up petroleum-hydrocarbon contaminated sites, consist of the biological decomposition of such organic pollutants by microorganisms that use them as carbon source to get energy, thereby releasing carbon dioxide, water, mineral salts and other gases (Banat et al., 2010). According to García et al. (2006), biodegradation of organic pollutants in the presence of surfactants happens when microorganisms use them as carbon and energy source. In this process, there is, firstly, the breakdown of hydrocarbon chains, which promotes a structural modification and immediate loss of amphipathicity. Then, the products of this first degradation are converted into $\mathrm{CO}_{2}$, water and minerals. The formation and accumulation of biosurfactants are related to a series of parameters that, according to Mukherjee et al. (2006), need further optimization in order to reach higher yields and lower costs. The promising future of biosurfactants depends on the use of low-cost raw materials and optimization of growth conditions to increase their production (Borges et al., 2015; Cortés-Camargo et al., 2016; Das and Das, 2015; Vedaraman and Venkatesh, 2011).

In this context, the aim of this work was to investigate the ability of biosurfactants released during cultivations of Bacillus subtilis, Bacillus megatherium, Bacillus licheniformisand Pseudomonas putida to promote toluene uptake in three aqueous media with different salinity, namely a low salinity medium, the Bushnell-Haas medium and a medium simulating seawater composition. For this purpose, the biosurfactant ability to lower the surface tension was evaluated. The process was finally scaled up to a bench-scale fermentor to evaluate the influence of salinity on the ability of the best biosurfactant producer, $B$. subtilis, to remove toluene.

\section{MATERIALS AND METHODS}

\section{Growth media}

The Bushnell-Haas medium (BH), with osmolarity of $110 \mathrm{mOsmol} / \mathrm{L}$ and surface tension (ST) of $74.0 \mathrm{mN} / \mathrm{m}$, had the following composition (mg/L): calcium chloride (23.0), magnesium sulfate (20.0), monobasic potassium phosphate (61.0), dibasic potassium phosphate (55.0), ammonium nitrate (50.0)and ferric chloride (69.0). The low salinity medium (LS), with osmolarity of $11 \mathrm{mOsmol} / \mathrm{L}$ and ST of $78.5 \mathrm{mN} / \mathrm{m}$, was prepared by $1: 10(\mathrm{v} / \mathrm{v})$ dilution of the $\mathrm{BH}$ medium with distilled water. The medium simulating seawater composition (SW), with osmolarity of 1,100 $\mathrm{mOsmol} / \mathrm{L}$ and ST of $74.5 \mathrm{mN} / \mathrm{m}$, was prepared pursuant to the adapted formulation of Bidwell and Spotte (1985) and had the following composition $(\mathrm{mg} / \mathrm{L})$ : calcium chloride (27.6), magnesium sulfate (6.9), magnesium chloride (5.4), calcium chloride (1.4), potassium chloride (0.6), sodium bicarbonate $(0.2)$, potassium bromide $(0.027)$, strontium chloride (0.02), manganese sulfate $(0.01)$, sodium phosphate $(0.01)$ and sodium molybdate $(0.001)$. 
All these saline media were supplemented or not with $3.0 \%(\mathrm{v} / \mathrm{v})$ toluene, corresponding to a starting toluene concentration of $26.0 \mathrm{~g} / \mathrm{L}$.

\section{Microorganisms}

The strains Bacillus subtilis ATCC 6051, Bacillus megatherium ATCC 14581 and Bacillus licheniformis ATCC 14580 were tested for their ability to uptake and degrade toluene in aqueous media, while Pseudomonas putida ATCC 12633 was selected as a reference strain for comparative purposes. All the strains were acquired from André Tosello Foundation (Campinas, SP, Brazil) and stored until use at $-80{ }^{\circ} \mathrm{C}$ in the $\mathrm{BH}$ medium containing $5 \%$ $(\mathrm{w} / \mathrm{v})$ yeast extract and $50 \%(\mathrm{v} / \mathrm{v})$ glycerol at $\mathrm{pH} 7.0$.

\section{Bacteria growth in shake flasks}

Pre-cultures were prepared by transferring $1.0 \mathrm{~mL}$ of each strain suspension into $100 \mathrm{~mL}$-flasks containing 15 $\mathrm{mL}$ of $\mathrm{BH}$ medium with $5 \%(\mathrm{w} / \mathrm{v})$ of yeast extract and incubating them at $30{ }^{\circ} \mathrm{C}$ and $200 \mathrm{rpm}$ in rotary shaker, model G-25KC (New Brunswick, Enfield, CT, USA) for $24 \mathrm{~h}$. Two $\mathrm{mL}$ of pre-cultures, corresponding to a cell concentration of about $0.05 \mathrm{~g} / \mathrm{L}$, were used to inoculate test tubes containing $20 \mathrm{~mL}$ of each saline medium and used in tests performed in a shaker at $200 \mathrm{rpm}$ and $30^{\circ} \mathrm{C}$ for $96 \mathrm{~h}$. The whole content of three test tubes was used for each microorganism after 48, 72 and $96 \mathrm{~h}$ to determine biosurfactant and biomass concentrations. Runs were carried out in triplicate, and the results expressed as mean values \pm standard deviations.

Controls were carried out with the same culture broths without inoculum in order to evaluate toluene loss by volatilization. In all cases studied, more than $95 \%$ of the initial toluene remained at the end of the process, thus eliminating the possible effect of toluene volatilization under the selected conditions.

\section{B. subtilis cultivation in the bioreactor}

B. subtilis, which showed the best performance in terms of ST reduction in flasks, was selected to perform cultivations in a 3-L bench-scale bioreactor, model BioFlo ${ }^{\circledR} /$ Celligen ${ }^{\circledR} 115$ (New Brunswick, Enfield, CT, USA), containing $1.5 \mathrm{~L}$ of the saline medium inoculated with 30 $\mathrm{mL}$ of microbial suspension and supplemented with 3.0 $(\mathrm{v} / \mathrm{v})$ toluene, corresponding to a starting concentration of $26.0 \mathrm{~g} / \mathrm{L}$. Volatilization of toluene was minimized by using a glass cooler at the exit of the bioreactor $\left(10^{\circ} \mathrm{C}\right)$, while the temperature inside the bioreactor was maintained at $30^{\circ} \mathrm{C}$ by recirculating water from a water bath, model Alpha RA 8 (Lauda, Delran, NJ, USA), into an external jacket. Precultures were harvested under similar conditions as earlier described. All the cultivations were carried out in triplicate at $30^{\circ} \mathrm{C}, 200 \mathrm{rpm}$ and $1.0 \mathrm{vvm}$ aeration for $42 \mathrm{~h}$, and the results expressed as mean values \pm standard deviations. Samples were taken at different times to determine ST and cell concentration. Material balances were made for each run resorting to a $\mathrm{CO}_{2}$ electrode, model InPro 5000 (Mettler-Toledo, Columbus, OH, USA), and their range of variation was 94.7 to $96.4 \%$.

\section{Analytical procedures}

Biomass concentration along the runs was determined by optical density (OD) measurements at $560 \mathrm{~nm}$ and expressed as dry cell concentration using a calibration curve. Samples $(5.0 \mathrm{~mL})$ were filtered through predried and weighed membrane filters with $0.45 \mu \mathrm{m}$ pores (Millipore, Billerica, MA) and then dried in an oven at $100^{\circ} \mathrm{C}$ for $24 \mathrm{~h}$.

Since the biosurfactant produced by the selected microorganisms had not yet been identified, no experimental methodology was available to detect its concentration directly. Therefore, the surface tension (ST) decrease along the runs was assumed to be directly proportional to the biosurfactant concentration. The ST of culture media was measured according to the Ring method described by Kim et al. (2000) using a tensiometer, model K9-Mk1 (Krüss, Hamburg, Germany), at $25 \pm 1^{\circ} \mathrm{C}$ and expressed in $\mathrm{mN} / \mathrm{m}$.

As far as the quantification of toluene is concerned, at first it was extracted using a 1:3(v/v) sample:chloroform ratio. The chloroform extract $(0.5 \mu \mathrm{L})$ was then injected into a gas chromatograph, model $7820 \mathrm{~A}$ (Agilent Technologies, Santa Clara, CA, USA), equipped with a HP-5 column containing $5 \%$ of phenyl methyl silicone $(30 \mathrm{~m} \times 0.32 \mathrm{~mm}$ ) with film width of $0.25 \mu \mathrm{m}$ (Agilent Technologies) and a flame ionization detector. Chromatographic analyses were carried out at initial temperature of $40^{\circ} \mathrm{C}$ for $1 \mathrm{~min}$, heating at $10^{\circ} \mathrm{C} / \mathrm{min}$ up to $80^{\circ} \mathrm{C}$, and keeping the system at this temperature for $1 \mathrm{~min}$. Helium was used as carrier gas at a flowrate of $28.5 \mathrm{~mL} / \mathrm{min}$.

The shape of all microorganisms was observed either at the beginning or the end of cultivations by an optic confocal microscope, model MRC-1024 (Bio-rad, Munich, Germany).

\section{RESULTS AND DISCUSSION}

\section{Growth of microorganisms in flasks and biosurfactant production}

Preliminary runs were performed using a rotary shaker to select, among different Bacillus species (namely $B$. subtilis, B. megatherium and B. licheniformis), the best biosurfactant producer in terms of surface tension reduction $\left(\mathrm{ST}_{\text {red }}\right)$. Bacteria were grown in media with different salinities either with or without toluene, while P. putida 
Table 1. Microbial growth of different strains in low salinity (LS), Bushnell-Haas (BH) and artificial sea water (SW) media in the absence of toluene.

\begin{tabular}{|c|c|c|c|c|c|c|c|}
\hline \multirow{2}{*}{$\begin{array}{c}\text { Medium } \\
\text { Strain }\end{array}$} & \multirow[b]{2}{*}{$\begin{array}{c}\text { Time } \\
\text { (h) }\end{array}$} & \multicolumn{2}{|c|}{$\mathbf{L S}$} & \multicolumn{2}{|c|}{ BH } & \multicolumn{2}{|c|}{ SW } \\
\hline & & $\begin{array}{c}\text { Biomass } \\
\text { concentration } \\
(\mathrm{g} / \mathrm{L})\end{array}$ & $\mathrm{ST}_{r e d}(\mathrm{~m} \mathbf{N} / \mathrm{m})$ & $\begin{array}{c}\text { Biomass } \\
\text { concentration } \\
(\mathrm{g} / \mathrm{L})\end{array}$ & $\mathrm{ST}_{r e d}(\mathrm{mN} / \mathrm{m})$ & $\begin{array}{c}\text { Biomass } \\
\text { concentration } \\
(\mathrm{g} / \mathrm{L})\end{array}$ & $\mathrm{ST}_{r e d}(\mathrm{mN} / \mathbf{m})$ \\
\hline \multirow{3}{*}{ B. subtilis } & 48 & $0.11 \pm 0.01^{\mathrm{a}}$ & $5.7 \pm 0.4$ & $0.20 \pm 0.02^{\mathrm{f}}$ & $3.5 \pm 0.5$ & $0.52 \pm 0.03^{\mathrm{i}}$ & $3.6 \pm 0.3$ \\
\hline & 72 & $0.24 \pm 0.01^{\mathrm{e}}$ & $8.4 \pm 0.5$ & $0.28 \pm 0.01^{\mathrm{i}}$ & $4.4 \pm 0.5$ & $0.80 \pm 0.03^{\mathrm{n}}$ & $4.4 \pm 0.5$ \\
\hline & 96 & $0.24 \pm 0.02^{\mathrm{e}}$ & $3.0 \pm 0.6$ & $0.26 \pm 0.01^{\mathrm{h}}$ & $0.6 \pm 0.6$ & $0.40 \pm 0.03^{\mathrm{f}}$ & $13.0 \pm 0.1$ \\
\hline \multirow{3}{*}{ B. licheniformis } & 48 & $0.20 \pm 0.02^{\mathrm{d}}$ & $11.8 \pm 0.3$ & $0.60 \pm 0.03^{p}$ & $0.3 \pm 0.3$ & $0.28 \pm 0.02^{b}$ & $0.8 \pm 0.2$ \\
\hline & 72 & $0.56 \pm 0.01^{\mathrm{j}}$ & $2.1 \pm 1.4$ & $0.62 \pm 0.03^{q}$ & $2.6 \pm 0.3$ & $0.76 \pm 0.01^{\mathrm{m}}$ & $0.4 \pm 0.3$ \\
\hline & 96 & $0.82 \pm 0.02^{\mathrm{k}}$ & $2.2 \pm 1.1$ & $0.35 \pm 0.02^{1}$ & $0.6 \pm 0.3$ & $0.28 \pm 0.02^{\mathrm{b}}$ & $2.8 \pm 0.3$ \\
\hline \multirow{3}{*}{ B. megatherium } & 48 & $0.28 \pm 0.02^{\mathrm{f}}$ & $0.1 \pm 0.1$ & $0.48 \pm 0.01^{\mathrm{n}}$ & $5.6 \pm 0.3$ & $0.20 \pm 0.02^{\mathrm{a}}$ & $2.6 \pm 0.5$ \\
\hline & 72 & $0.26 \pm 0.03^{\mathrm{ef}}$ & $4.7 \pm 0.4$ & $0.60 \pm 0.02^{\mathrm{p}}$ & $2.4 \pm 0.5$ & $0.44 \pm 0.02^{\mathrm{h}}$ & $1.7 \pm 0.4$ \\
\hline & 96 & $0.34 \pm 0.02^{\mathrm{gh}}$ & $1.6 \pm 0.5$ & $0.32 \pm 0.01^{\mathrm{k}}$ & $2.6 \pm 0.54$ & $0.32 \pm 0.03^{\mathrm{d}}$ & $1.6 \pm 0.6$ \\
\hline \multirow{3}{*}{ P. putida } & 48 & $0.32 \pm 0.01^{\mathrm{g}}$ & $12.4 \pm 0.8$ & $0.60 \pm 0.02^{p}$ & $16.4 \pm 0.5$ & $1.32 \pm 0.01^{\mathrm{q}}$ & $7.6 \pm 0.3$ \\
\hline & 72 & $0.32 \pm 0.01^{\mathrm{g}}$ & $21.2 \pm 1.1$ & $1.01 \pm 0.02^{\mathrm{r}}$ & $9.6 \pm 0.5$ & $0.62 \pm 0.01^{\mathrm{k}}$ & $11.8 \pm 0.3$ \\
\hline & 96 & $0.36 \pm 0.02^{\mathrm{h}}$ & $7.2 \pm 1.1$ & $0.36 \pm 0.02^{1}$ & $12.4 \pm 0.4$ & $0.72 \pm 0.03^{1}$ & $3.8 \pm 0.3$ \\
\hline
\end{tabular}

was tested as a control microorganism for comparison purposes, taking into account that it has been thoroughly studied just because of its high biosurfactant production capacity (Aparna et al., 2011). Biomass concentration of the selected microorganisms in the media employed for this study varied widely either in the absence $(0.11 \pm$
$0.01 \mathrm{~g} / \mathrm{L}$ to $1.32 \pm 0.01 \mathrm{~g} / \mathrm{L})($ Table 1$)$ or in the presence $(0.08 \pm 0.01 \mathrm{~g} / \mathrm{L}$ to $1.02 \pm 0.01 \mathrm{~g} / \mathrm{L})$ (Table 2) of toluene. Microscopic examinations made both at the beginning and the end of cultivations did not reveal any apparent morphological change in any of the microorganisms employed in this study.

Table 2. Microbial growth of different strains in low salinity (LS), Bushnell-Haas (BH) and artificial sea water (SW) media in the presence of toluene.

\begin{tabular}{|c|c|c|c|c|c|c|c|}
\hline \multicolumn{2}{|l|}{ Medium } & \multicolumn{2}{|c|}{ LS } & \multicolumn{2}{|c|}{ BH } & \multicolumn{2}{|c|}{ SW } \\
\hline Strain & $\begin{array}{c}\text { Time } \\
\text { (h) }\end{array}$ & $\begin{array}{l}\text { Biomass con- } \\
\text { centration } \\
(\mathrm{g} / \mathrm{L})\end{array}$ & $\mathrm{ST}_{r e d}(\mathrm{mN} / \mathbf{m})$ & $\begin{array}{l}\text { Biomass con- } \\
\text { centration } \\
(\mathrm{g} / \mathrm{L})\end{array}$ & $\mathrm{ST}_{\text {red }}(\mathrm{mN} / \mathrm{m})$ & $\begin{array}{c}\text { Biomass con- } \\
\text { centration } \\
(\mathrm{g} / \mathrm{L})\end{array}$ & $\mathrm{ST}_{r e d}(\mathrm{~m} \mathbf{N} / \mathbf{m})$ \\
\hline \multirow{3}{*}{ B. subtilis } & 48 & $0.16 \pm 0.02^{\mathrm{c}}$ & $23.5 \pm 0.7$ & $0.08 \pm 0.01^{\mathrm{a}}$ & $20.5 \pm 0.7$ & $0.34 \pm 0.03^{\mathrm{e}}$ & $21.7 \pm 0.4$ \\
\hline & 72 & $0.16 \pm 0.01^{\mathrm{c}}$ & $23.5 \pm 0.7$ & $0.14 \pm 0.01^{\mathrm{c}}$ & $27.3 \pm 0.3$ & $0.40 \pm 0.02^{\mathrm{f}}$ & $20.6 \pm 0.3$ \\
\hline & 96 & $0.11 \pm 0.01^{\mathrm{a}}$ & $22.3 \pm 0.5$ & $0.10 \pm 0.01^{\mathrm{b}}$ & $27.5 \pm 0.5$ & $0.40 \pm 0.02^{\mathrm{f}}$ & $23.4 \pm 0.3$ \\
\hline \multirow{3}{*}{ B. licheniformis } & 48 & $0.11 \pm 0.02^{\mathrm{a}}$ & $24.6 \pm 0.6$ & $0.46 \pm 0.03^{\mathrm{m}}$ & $24.5 \pm 0.6$ & $0.28 \pm 0.02^{\mathrm{b}}$ & $19.7 \pm 0.3$ \\
\hline & 72 & $0.12 \pm 0.03^{\mathrm{ab}}$ & $23.3 \pm 0.5$ & $0.26 \pm 0.02^{\mathrm{h}}$ & $24.5 \pm 0.5$ & $0.30 \pm 0.01^{\mathrm{c}}$ & $19.7 \pm 0.4$ \\
\hline & 96 & $0.11 \pm 0.02^{\mathrm{a}}$ & $22.2 \pm 1.1$ & $0.16 \pm 0.03^{\mathrm{d}}$ & $12.6 \pm 0.3$ & $0.28 \pm 0.01^{\mathrm{b}}$ & $17.6 \pm 0.6$ \\
\hline \multirow{3}{*}{ B. megatherium } & 48 & $0.14 \pm 0.03^{\mathrm{bc}}$ & $19.5 \pm 0.6$ & $0.52 \pm 0.01^{\circ}$ & $20.5 \pm 0.6$ & $0.30 \pm 0.02^{\mathrm{c}}$ & $20.7 \pm 0.3$ \\
\hline & 72 & $0.12 \pm 0.03^{\mathrm{ab}}$ & $25.6 \pm 0.6$ & $0.22 \pm 0.01^{\mathrm{g}}$ & $20.6 \pm 0.5$ & $0.54 \pm 0.02^{\mathrm{j}}$ & $19.9 \pm 0.1$ \\
\hline & 96 & $0.14 \pm 0.02^{\mathrm{bc}}$ & $18.8 \pm 0.4$ & $0.08 \pm 0.02^{\mathrm{a}}$ & $17.6 \pm 0.5$ & $0.28 \pm 0.03^{\mathrm{b}}$ & $17.0 \pm 0.2$ \\
\hline \multirow{3}{*}{ P. putida } & 48 & $0.48 \pm 0.02^{\mathrm{i}}$ & $25.8 \pm 0.9$ & $0.35 \pm 0.03^{1}$ & $33.6 \pm 0.4$ & $1.02 \pm 0.01^{\mathrm{p}}$ & $25.4 \pm 0.2$ \\
\hline & 72 & $0.12 \pm 0.02^{\mathrm{ab}}$ & $15.1 \pm 1.2$ & $0.30 \pm 0.03^{\mathrm{j}}$ & $23.7 \pm 0.4$ & $0.42 \pm 0.01^{\mathrm{g}}$ & $21.7 \pm 0.4$ \\
\hline & 96 & $0.28 \pm 0.01^{\mathrm{f}}$ & $0.8 \pm 0.3$ & $0.18 \pm 0.01^{\mathrm{e}}$ & $21.5 \pm 0.6$ & $0.82 \pm 0.02^{\circ}$ & $22.0 \pm 0.3$ \\
\hline
\end{tabular}


In the low salinity (LS) medium without toluene, $B$. licheniformis grew better than all the other microorganisms, reaching a biomass concentration $(0.82 \pm 0.02 \mathrm{~g} / \mathrm{L})$ after $96 \mathrm{~h}$ of cultivation even higher than the control (P. putida) $(0.36$ $\pm 0.02 \mathrm{~g} / \mathrm{L})$ (Table 1). On the other hand, the presence of toluene was detrimental for all the selected microorganisms but the control, in that it reduced considerably their growth. As a matter of fact, the cell concentration of B. subtilis, which was the microorganism that showed the fastest growth, did not exceed $0.16 \pm 0.02 \mathrm{~g} / \mathrm{L}$ after $72 \mathrm{~h}$ (Table 2).

As far as the Bushnell-Haas (BH) medium is concerned, its intermediate salinity seemed to stimulate the growth of all the microorganisms under almost all the conditions tested compared to the LS one. In the absence of toluene, $B$. licheniformis showed again the highest growth among the tested bacilli, achieving a biomass concentration after only 48 has high as $0.62 \pm 0.03 \mathrm{~g} / \mathrm{L}$ (Table 1), while in the presence of toluene the highest growth was obtained with $B$. megatherium after the same time $(0.52 \pm 0.01$ $\mathrm{g} / \mathrm{L}$ ) (Table 2). Nonetheless, biomass concentration was remarkably reduced at longer times either in the presence or in the absence of toluene.

Using the medium simulating seawater (SW) composition, i.e., that with the highest salinity, $B$. subtilis and $B$. licheniformis reached the highest biomass concentrations in the absence of toluene $(0.80 \pm 0.03 \mathrm{~g} / \mathrm{L}$ and $0.76 \pm 0.01 \mathrm{~g} / \mathrm{L}$, respectively), but after longer time (72h) compared to the $\mathrm{BH}$ medium, which suggests that these microorganisms require a long adaptation period in the presence of high salt levels. In the same medium supplemented with toluene (Table 2), B. subtilis showed more stable growth compared with the other bacilli, with an average cell concentration of $0.38 \mathrm{~g} / \mathrm{L}$ during the whole run, thus behaving as the strain more resistant to highly salty conditions.

As regards the capacity of the selected microorganisms to produce biosurfactants, Fig. 1 illustrates their ability to reduce the surface tension either with or without toluene, while the corresponding values of $\mathrm{ST}_{\text {red }}$ are listed in Tables 1 and 2.

It is usually assumed that a compound has to be able to reduce ST by at least $8 \mathrm{mN} / \mathrm{m}$ to be considered a surfactant (Van der Vegt et al., 1991). As shown in Table 1, in the absence of toluene, B. subtilis was able to reduce ST of the LS medium by $8.4 \pm 0.5 \mathrm{mN} / \mathrm{m}$ after $72 \mathrm{~h}$ and that of the $\mathrm{SW}$ medium by $13.0 \pm 0.1 \mathrm{mN} / \mathrm{m}$ after $96 \mathrm{~h}$. Reducing ST by $11.8 \pm 0.3 \mathrm{mN} / \mathrm{m}$ after $48 \mathrm{~h}$, B. licheniformis behaved even better than B. subtilis in the LS medium but not in the $\mathrm{SW}$ one, whereas $B$. megatherium was disappointing in all the culture media tested, reducing the surface tension by a maximum of $5.5 \pm 0.3 \mathrm{mN} / \mathrm{m}$ in the $\mathrm{BH}$ medium.

To select the best microorganism to be used in future bioremediation applications, we tried to make an overall comparison among the $\mathrm{ST}_{\text {red }}$ skills of the selected bacilli. The results of Table 1 show that, in spite of the poor results in terms either of cell concentration or $\mathrm{ST}_{\text {red }}$ in the LS medium without toluene, $B$. subtilis was capable of reducing the ST more than B. megatherium and B. licheniformis in the other media. According to Desai and Banat (1997), efficient biosurfactants have low critical micelle concentration (CMC), i.e., a small quantity of surfactant is needed to reduce ST, which suggests that the biosurfactant produced by $B$. subtilis could have been more effective than those produced by the other species. Conversely, P. putida (used as control for comparison) was the microorganism that showed the best cell growth and that mostly reduced ST in almost all the systems without toluene. The ST reduction was the highest in the LS medium after $72 \mathrm{~h}(21.2 \pm 1.1$ $\mathrm{mN} / \mathrm{m}$ ) and decreased almost proportionally to the increase in salinity $(16.4 \pm 0.5 \mathrm{mN} / \mathrm{m}$ in the $\mathrm{BH}$ and $11.8 \pm 0.3 \mathrm{mN} / \mathrm{m}$ in the SW media, respectively).

But the most interesting finding is that the use of toluene as a carbon source significantly stimulated the short-term production of biosurfactants at the expense of growth. Regardless of the salinity level of the media, all microorganisms tested did in fact ensure ST reductions greater than $19 \mathrm{mN} / \mathrm{m}$ within only $48 \mathrm{~h}$. Our general conclusion is that toluene may have enhanced biosurfactant production, hence indirectly enhancing non-specific permeability of the cytoplasmic membrane and resulting in ATP leakage (Rodrigues et al., 2006).

The best performance was observed again with the control, with a ST reduction of $33.6 \pm 0.4 \mathrm{mN} / \mathrm{m}$ in the $\mathrm{BH}$ medium. However, this reduction considerably decreased with increasing fermentation time. In particular, in the LS medium the ST reduction decreased from $25.8 \pm 0.9$ $\mathrm{mN} / \mathrm{m}$ after $48 \mathrm{~h}$ to only $0.8 \pm 0.3 \mathrm{mN} / \mathrm{m}$ after $96 \mathrm{~h}$. These values are in fair agreement with those of Haghighat et al. (2008), who reported for B. Licheniformis and B. subtilis cultivated in a rotary shaker on raw oil $(2 \%)$ as carbon source, under the same conditions as the present study, ST reductions of 30 and $29 \mathrm{mN} / \mathrm{m}$, respectively, after $48 \mathrm{~h}$ of growth. However, the raw oil employed by these authors comprised several different carbon sources, while toluene was the only source used in this study besides yeast extract.

Mnif et al. (2001), who used petroleum-derived hydrocarbons, reported that the tested strains, among which a $B$. licheniformis strain isolated from oil fields, did not show any capacity of using toluene as a carbon source. Consistently, Nicholson and Fathepure (2004) observed that only $0.004 \%$ of toluene was consumed along a 7 day-run in a rotary shaker, while the same concentration of benzene, ethylbenzene and xylene needed approximately 15 days to be metabolized. These observations are consistent with the well-known harmful effects and great difficulty to remove toluene from the environment. 


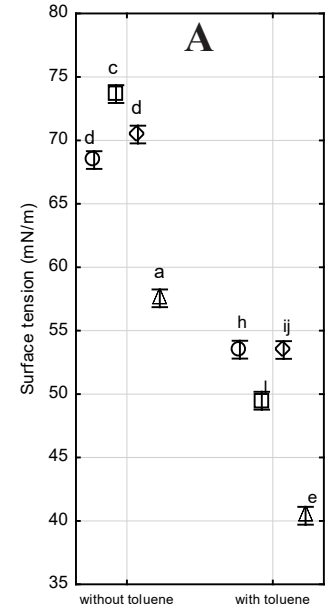

$48 \mathrm{~h}$

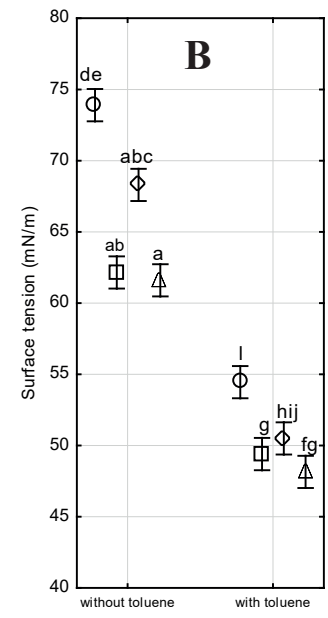

$48 \mathrm{~h}$

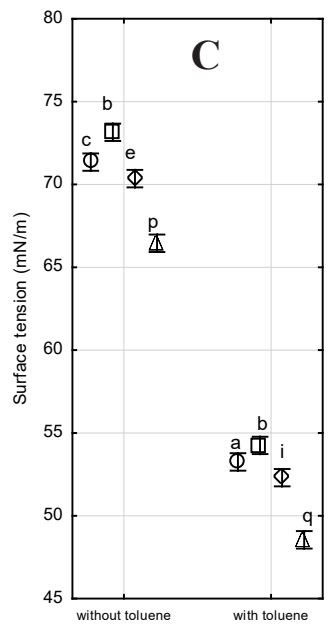

$48 \mathrm{~h}$
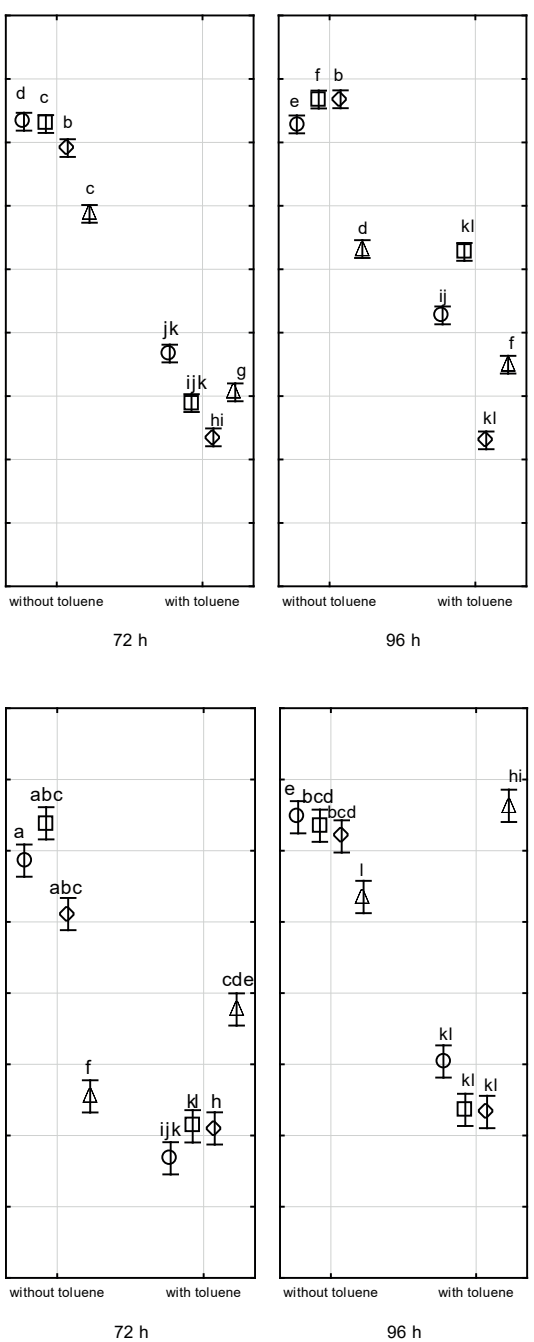

$96 \mathrm{~h}$
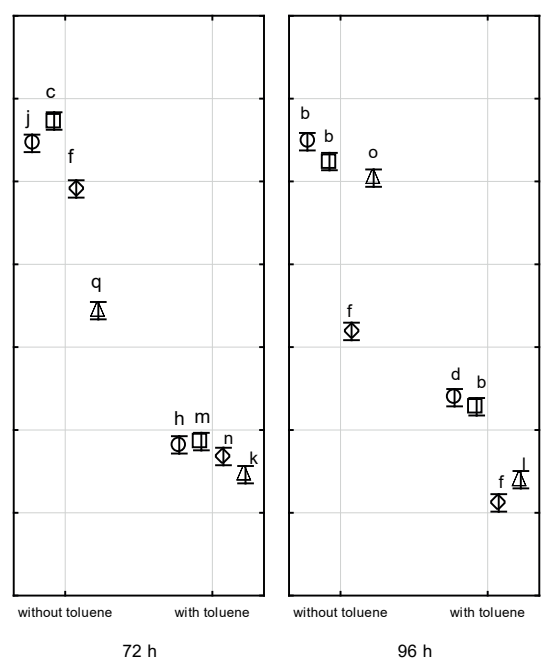

Figure 1. Surface tension values obtained using different culture media [LS medium (A), BH medium (B) and SW medium (C)] at different fermentation times (48, 72 and $96 \mathrm{~h}$ ), in the absence or the presence of toluene. Biosurfactant producers: Bacillus licheniformis $(\square)$, Bacillus megatherium $(\bigcirc)$, Bacillus subtilis $(\diamond)$ and Pseudomonas putida $(\triangle)$. Mean values $(\mathrm{n}=3) \pm$ standard deviations. Different letters in the same column mean that values differ significantly among them $(P<0.05)$. 


\section{Production of biosurfactant in the bench-scale bioreactor}

Based on the results of previous experiments performed in a rotary shaker, which demonstrated that an organic carbon source like toluene can stimulate the production of biosurfactants, $B$. subtilis was selected to scale up the process to a bench-scale bioreactor. Several researches studying bioremediation of aqueous media contaminated by hydrocarbons reported starting ST values close or higher than $65 \mathrm{mN} / \mathrm{m}$, and a subsequent reduction to less than $35 \mathrm{mN} / \mathrm{m}$, depending on the capacity of bacteria to produce biosurfactants (Haghighat et al., 2008; Nicholson and Fathepure, 2004; Xia et al., 2011).

As shown in Fig. 2A, illustrating the growth of $B$. subtilis in the LS medium, the ST was initially $73.5 \mathrm{mN} / \mathrm{m}$, remained almost constant for about $12 \mathrm{~h}$, then decreased simultaneously with the microbial growth, and was reduced by $17.2 \mathrm{mN} / \mathrm{m}$ after $15 \mathrm{~h}$. Biomass continued to grow until $24 \mathrm{~h}$, reaching a maximum cell concentration of $0.36 \mathrm{~g} / \mathrm{L}$, while the concentration of toluene in the medium decreased from 26.0 to only $4.3 \mathrm{~g} / \mathrm{L}$ after 12 h. Such a low biomass yield could have been due to the use of non-adapted cells in addition to the same energyconsuming biosurfactant production. The inoculum was in fact prepared in a medium where yeast extract was the only carbon source, while subsequent runs were done under different conditions, i.e., variable salinity and the presence of toluene as additional carbon source in this run. The ST kept almost constant between 18 and $38 \mathrm{~h}$ likely due to reaching the biosurfactant $\mathrm{CMC}$ during the exponential phase of B. subtilis growth; in fact, as suggested by several authors, when micelle formation starts, the ST in the fluid does not vary (Desai and Banat, 1997; Soberón-Chávez and Maier, 2010).

Recently, Vaz et al. (2012), after observing a significant decrease in the ST from 4 to $24 \mathrm{~h}$ of fermentation, when the lowest value of ST $(30.1 \mathrm{mN} / \mathrm{m})$ was reached, concluded that biosurfactant production is associated with growth. Likewise, a decrease in the ST from 71.2 to $27 \mathrm{mN} / \mathrm{m}$ was observed by Xia et al. (2011) with B. subtilis just at the beginning of the run, thus confirming a growth-associated production of biosurfactant.

In the present study, after $24 \mathrm{~h}$ the cell concentration decreased from 0.36 to $0.16 \mathrm{~g} / \mathrm{L}$ at the end of the run (Fig. 2A). Considering that more than $84 \%$ of the toluene was consumed within the first $15 \mathrm{~h}$, the only alternative carbon source for the microorganism might have been the produced biosurfactant itself (García et al., 2006), as confirmed by the final ST increase in the LS medium up to $61.3 \mathrm{mN} / \mathrm{m}$.

Runs in the $\mathrm{BH}$ medium (Fig. 2B) showed results a little different from those obtained in the LS medium (Fig. $2 \mathrm{~A})$. Biomass concentration was in fact higher $(0.90 \mathrm{~g} / \mathrm{L})$, and, consequently, the ST progressively reduced up to the end of the run. Regarding the SW medium (Fig. 2C), the ST decreased from $73.1 \mathrm{mN} / \mathrm{m}$ at the start to $67.1 \mathrm{mN} / \mathrm{m}$ after $15 \mathrm{~h}$, i.e., to a value that was practically the same as those obtained in the BH and LS media (Figs. 2A and 2B).

In the SW medium (Fig. 2C), the toluene concentration remained practically constant $(26.0-24.1 \mathrm{~g} / \mathrm{L})$ during the first $12 \mathrm{~h}$, and then suddenly decreased to $0.11 \mathrm{~g} / \mathrm{L}$ up to 15 $\mathrm{h}$, a period during which biosurfactant was produced. These results confirm that $B$. subtilis utilized toluene as primary carbon source to sustain both its growth and biosurfactant production. Many authors supported the extracellular nature of biosurfactants produced by Bacillus sp. (Desai and Banat, 1997; Aparna et al., 2011; Cortés-Camargo et al., 2016). Consistently, Pinto et al. (2009) observed that there was no significant difference between ST values of the medium with $(58.7 \mathrm{mN} / \mathrm{m})$ or without $(56.7 \mathrm{mN} / \mathrm{m}) B$. subtilis cells, hence concluding that the biosurfactant was extracellularly released.

Fig. 3A shows that foam formation by B. subtiliscultures in the LS medium started after about $12 \mathrm{~h}$, remarkably increased after $24 \mathrm{~h}$ and continued until the end of the run (42 h). The behavior was qualitatively similar in the $\mathrm{BH}$ medium, but the production of foam was so pronounced that it occupied the bioreactor almost completely (Fig. 3B). Similarly, Chen et al. (2006) observed foam formation after $12 \mathrm{~h}$ with $B$. subtilis grown in M9 medium with $0.2 \%$ glucose. According to Winterburn and Martin (2012), the operating conditions of the fermentor such as aeration and stirring rate have a strong influence on foam formation, in that foam tends to accumulate on the surface of the growth medium, but if there is enough aeration or stirring rate, it will blend back and return to the medium.

Regarding the SW medium (Fig. 3C), foam production was lower than in the LS and BH media, as the likely result of its high salt content (osmolarity of 1,100 $\mathrm{mOsm} / \mathrm{L}$ ) and low ST reduction capability. According to Hanna et al. (2005), the presence of salt in the solution would in fact be responsible for a decrease in the electrostatic repulsive forces and allow for the approximation of the polar part, thus favoring the biosurfactant micellization vertically, like a highly flexible and endless rod, with micelle agglomeration. This rod with a higher number of biosurfactant monomers was described by Zhai et al. (2006) as a vesicle.

Chen et al. (2006) observed that, after $14 \mathrm{~h}$ of growth, the concentration of the biosurfactant produced by $B$. subtilis was $32.5 \mathrm{mg} / \mathrm{L}$ in the M9 medium and 1.79 $\mathrm{mg} / \mathrm{L}$ in the foam; therefore, they concluded that, when the biosurfactant concentration exceeds the $\mathrm{CMC}$, foam formation begins, and micelles tend to accumulate, acting as a surfactant reservoir. Consistent with these observations, in our work, the CMC was reached after approximately 18 $\mathrm{h}$, and foam formation appeared a little after (24 h). Foam formation is important in fermentation processes devoted to the production of extracellular biosurfactants; in fact, 

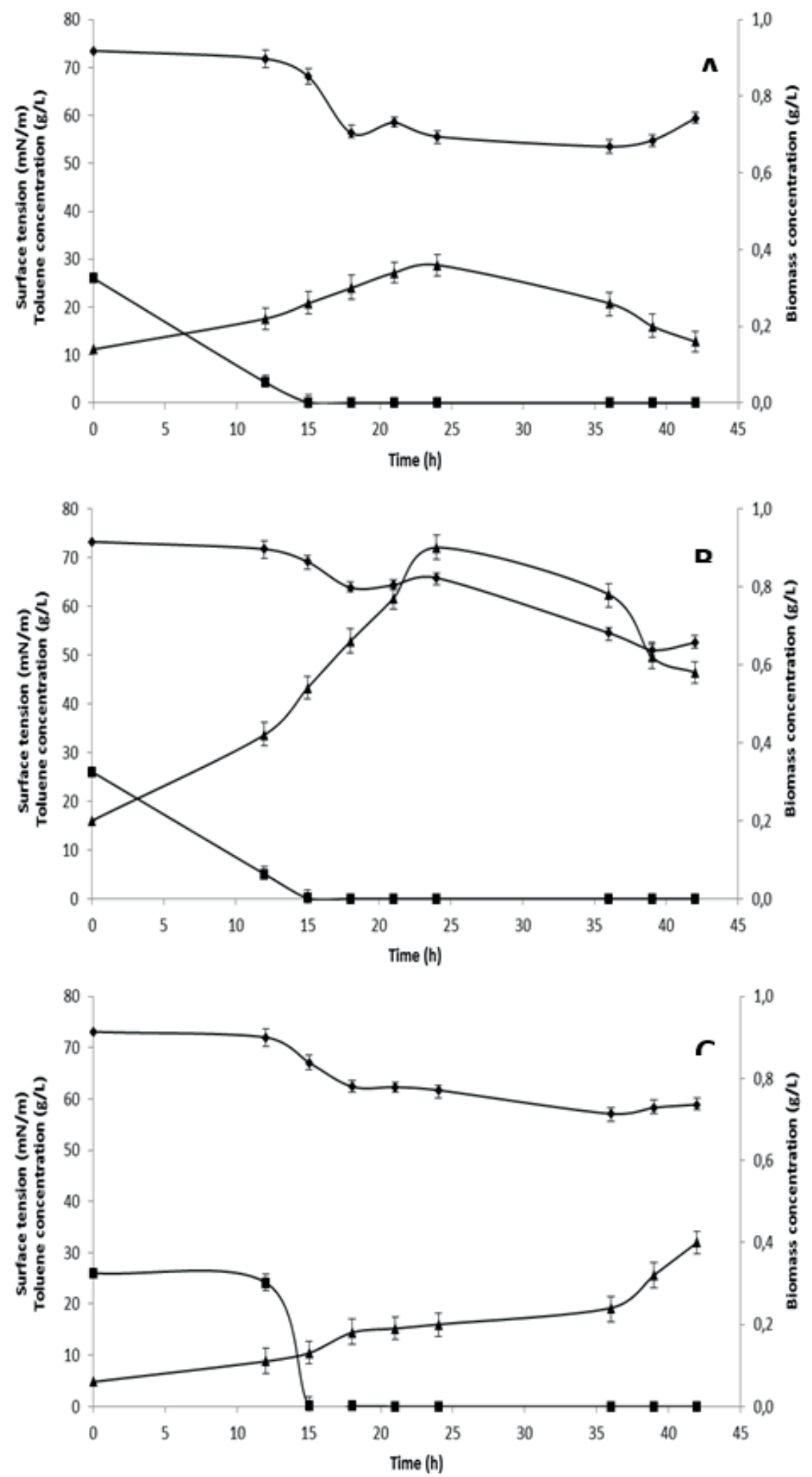

Figure 2. Bacillus subtilis cultivations in the bench-scale bioreactor in the presence of toluene. Surface tension $(\diamond)$, toluene concentration ( $\mathbf{\square})$, and biomass concentration $(\mathbf{A})$ in LS (A), BH (B) and SW (C) media. 

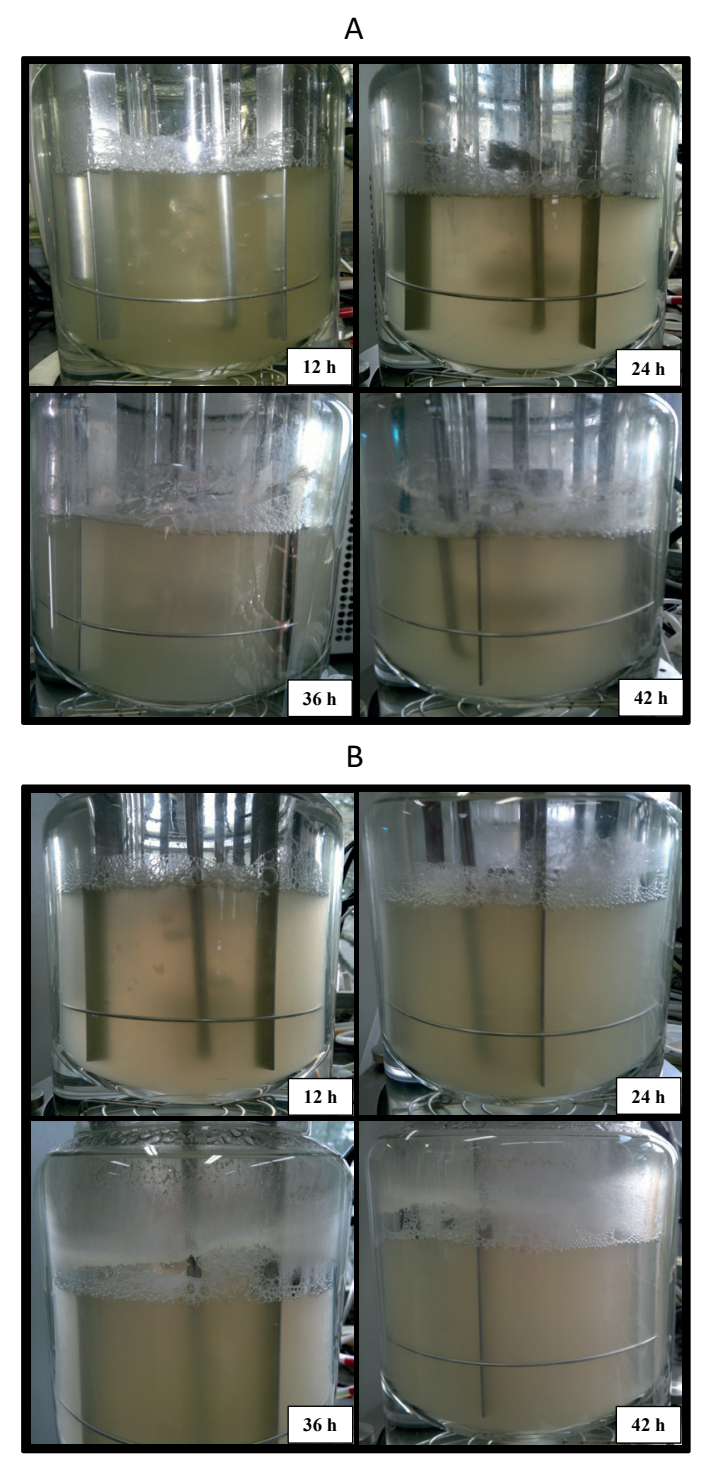

C

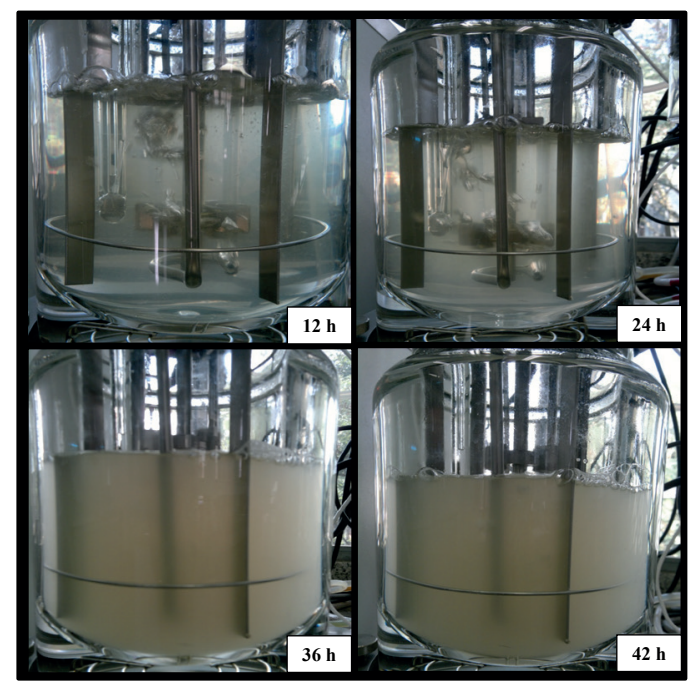

Figure 3. Foam formation in the bench-scale fermentor during cultivations of Bacillus subtilis. LS (A), BH (B) and SW (C) media in the presence of toluene. 
acting as a reservoir, foam makes biosurfactant recovery easier (Junker, 2007).

\section{CONCLUSIONS}

Among the microorganisms belonging to the Bacillus genus used in this work, B. subtilis proved to be the most effective producer of biosurfactant in the selected media, namely low saline medium, BH medium and a medium simulating seawater composition. The presence of toluene in the media enhanced the production of biosurfactants at the expense of microbial growth. During fermentation, the likely formation of large vesicles rather than simple micelles could have promoted the breakdown of hydrocarbon molecules and the quick consumption of toluene as the main carbon source. The results obtained in this study suggest that $B$. subtilis could be an interesting microorganism to be used in the bioremediation of toluene-contaminated waters, although further process optimizations are required.

\section{ACKNOWLEDGEMENTS}

The authors gratefully acknowledge financial support by the São Paulo Research Foundation (FAPESP, grant number 2013/15065-0). The authors also thank the Coordination of High-Level Personnel Training (CAPES) for financial support of Prof. Converti (Science without Borders Program, ref. n. A003_2013, process 2609/2013) and Prof. Domínguez (Science without Borders Program, process 88881.062223/2014-01). The authors extend their appreciation to the Deanship of Scientific Research at King Saud University, Riyadh, Kingdom of Saudi Arabia for funding this work through the International Research Group Project No IRG14-24.

\section{REFERENCES}

Aparna, A., Srinikethan, G., Hedge, S., Effect of addition of biosurfactant produced by Pseudomonas spp. on biodegradation of crude oil. International Proceedings of Chemical, Biological and Environmental Engineering,6, p. 1071-1075 (2011).

Asimiea, O.A., Sam-Wobo, S.O., The impact of hydrocarbon waste from brass oil terminal on the phytoplancton and periphyton comunities of lower brass river, Niger delta, Nigeria. Journal of Emerging Trends in Engineering and Applied Sciences, 2, p. 729733 (2011).

Banat, I.M., Franzetti, A., Gandolfi, I., Bestetti, G., Martinotti, M.G., Fracchia, L., Smyth, T.J.P., Marchant, R., Microbial biosurfactants production, applications and future potential. Applied Microbiology and Biotechnology, 87, p. 427-444 (2010).
Bidwell, J.P., Spotte, S., Artificial seawaters - formulas and methods. Jones and Bartlett publishers, Boston (1985).

Borges, W. S., Moura, A. A. O., Coutinho Filho, U., Cardoso, V. L., and Resende, M. M., Optimization of the operating conditions for rhamnolipid production using slaughterhouse-generated industrial float as substrate. Brazilian Journal of Chemical Engineering, 32(2), 357-365 (2015).

Chen, C.Y., Baker, S.C., Darton, R.C., Batch production of biosurfactant with foam fractionation. Journal of Chemical Technology and Biotechnology, 81, p. $1923-$ 1931 (2006).

Cortés-Camargo, S., Pérez-Rodríguez, N., Oliveira, R.P.S., Huerta, B.E.B., Domínguez, J.M., Production of biosurfactants from vine-trimming shoots using the halotolerant strain Bacillus tequilensis ZSB10. Industrial Crops and Products, 79, p. 258-266 (2016).

Costa, A.S., Romão, L.P.C., Araújo, B.R., Lucas, S.C.O., Maciel, S.T.A., Wisniewski Jr, A., Alexandre, M.R., Environmental strategies to remove volatile aromatic fractions (BTEX) from petroleum industry wastewater using biomass. Bioresource Technology, 105, p. 31-39 (2012).

Das, S., and Das, P.; Effects of cultivation media components on biosurfactant and pigment production from Pseudomonas aeruginosa PAO1. Brazilian Journal of Chemical Engineering, 32(2), 317-324 (2015).

Desai, J.D., Banat, I.M., Microbial production of surfactants and their commercial potential.Microbiology and Molecular Biology Reviews, 61, p. 47-64 (1997).

Di Martino, C., López, N.I., Iustman, L.J.R., Isolation and characterization of benzene, toluene and xylene degrading Pseudomonas sp. selected as candidates for bioremediation. International Biodeterioration and Biodegradation, 67, p. 15-20 (2012).

Du, J., Chadalavada, S., Chen, Z., Naidu, R., Environmental remediation techniques of tributyltin contamination in soil and water: A review. Chemical Engineering Journal, 235, p. 141-150 (2014).

Fellenberg, G., Introduction of environment pollution problems. $1^{\text {st }}$ ed., EPU, University of São Paulo, Brazil (1980).

García, M.T., Campos, E., Dalmau, M., Illán, P., SánchezLeal, J., Inhibition of biogas production by alkyl benzene sulfonates (LAS) in a screening test for anaerobic biodegradability. Biodegradation, 17, p. 3946 (2006).

Goldman, R., Biton, E., Brokovich, E., Kark, S., Levin, N., Oil spill contamination probability in the southeastern Levantine basin. Marine Pollution Bulletin, 91, p. 347356 (2015). 
Haghighat, S., Akhavan, A.S., Mazaheri, A.M., Pasdar, H., Ability of indigenous Bacillus licheniformis and Bacillus subtilis in microbial enhanced oil recovery. International Journal of Environmental Science and Technology, 5, p. 385-390 (2008).

Hanna, K., Denoyel, R., Beurroides, I., Dubès, J.P., Solubilization of pentachlorophenol in micelles and confined surfactant phases. Colloids and Surfaces A: Physicochemical and Engineering Aspects, 254, 231239 (2005).

Janbandhu, A., Fulekar, M.H., Biodegradation of phenanthrene using adapted microbial consortium isolated from petrochemical contaminated environment. Journal of Hazardous Materials, 187, p. 333-340 (2011).

Junker, B., Foam and its mitigation in fermentation systems. Biotechnology Progress, 23, p. 767-784 (2007).

Kavitha, V., Mandal, A.B., Gnanamani, A., Microbial biosurfactant mediated removal and/or solubilization of crude oil contamination from soil and aqueous phase: An approach with Bacillus licheniformis MTCC 5514. International Biodeterioration and Biodegradation, 94, p. 24-30 (2014).

Kim, S., Lim, E., Lee, S., Lee, J., Lee, T., Purification and characterization of biosurfactants from Nocardia sp. L-417. Biotechnology and Applied Biochemistry, 31, p. 249-253 (2000).

Lin, C.W., Wu, C.H., Tang, C.T., Chang, S.H., Novel oxygenreleasing immobilized cell beads for bioremediation of BTEX-contaminated water. Bioresource Technology, 124, p. 45-51 (2012).

Mariano, A.P., Kataoka, A.P.A.G., Angelis, D.F., Bonotto, D.M., Laboratory study on the bioremediation of diesel oil contaminated soil from a petrol station. Brazilian Journal of Microbiology, 38, p. 346-353 (2007).

Mnif, S., Chamkha, M., Labat, M., Sayadi, S., Ability of indigenous Bacillus licheniformis and Bacillus subtilis in microbial enhanced oil recovery. Journal of Applied Microbiology, 111, p. 525-536(2011).

Mukherjee, S., Das, P., Sen, R., Towards commercial production of microbial surfactants. Trends Biotechnology, 24, p. 509-515 (2006).

Nicholson, C.A., Fathepure, B.Z., Biodegradation of benzene by halophilic and halotolerant bacteria under aerobic conditions. Applied and Environmental Microbiology, 70, 1222-1225 (2004).

Pinto, M.H., Martins, R.G., Costa, J.A.V., Evaluation of the kinetic production of bacterial biosurfactants. Quimica Nova, 32, p. 2104-2108 (2009).
Rodrigues, L.,Banat, I.M., Teixeira, J., Oliveira, R., Biosurfactants: potentialapplications in medicine. Journal of Antimicrobial Chemotherapy, 57, 609-618 (2006).

Soberón-Chávez, G., Maier, R.M., Biosurfactants: a general overview. In: G. Soberón-Chávez (ed) Biosurfactants: From Genes to Applications. Springer, Germany (2010).

Souza, E.C., Production and biosurfactant action produced by bacteria in diferente saline media contaminated with aromatic hydrocarbons (in portuguese). 166 p. (master's thesis) University of São Paulo, Brazil (2013).

Van der Vegt, W., Van der Mei, H.C., Noordmans, J., Busscher, H.J., Assessment of bacterial biosurfactant production through axisymmetric drop shape analysis by profile.Applied Microbiology and Biotechnology, 35, p. 766-770 (1991).

Vaz, D.A., Gudiña, E.J., Alameda, E.J., Teixeira, J.A., Rodrigues, L.R., Performance of a biosurfactant produced by a Bacillus subtilis strain isolated from crude oil samples as compared to commercial chemical surfactants. Colloids and Surfaces B: Biointerfaces, 89, p. 167- 174 (2012).

Vedaraman, N., and Venkatesh, N., Production of surfactin by Bacillus subtilis MTCC 2423 from waste frying oils. Brazilian Journal of Chemical Engineering, 28(2), 175-180 (2011).

WHO - World Health Organization., Guidelines for drinking-water quality: incorporating first addendum, 3rd ed. Recommendations, Switzerland (2006).

Winterburn, J.B., Martin, P.J., Foam mitigation and exploitation in biosurfactant production. Biotechnology Letters, 34, p. 187-195 (2012).

Xia, W.J., Dong, H.P., Yu, L., Yu, D.F., Comparative study of biosurfactant produced by microorganisms isolated from formation water of petroleum reservoir. Colloids and Surfaces A: Physicochemical and Engineering Aspects, 392, p. 124-130 (2011).

Zhai, L., Tan, X., Li, T., Chen, Y., Huang, X., Influence of salt and polymer on the critical vesicle concentration in aqueous mixture of zwitterionic/anionic surfactants. Colloids and Surfaces A: Physicochemical and Engineering Aspects, 276, 28-33 (2006).

Zhang, L., Zhang, C., Cheng, Z., Yao, Y., Chen, J., Biodegradation of benzene, toluene, ethylbenzene, and o-xylene by the bacterium Mycobacterium cosmeticum byf-4. Chemosphere, 90, p. 1340-1347 (2013). 